\title{
EKSPLORASI JAMUR MAKROSKOPIS DI PERKEBUNAN KELAPA SAWIT
}

\author{
Reny Dwi Riastuti ${ }^{1}$, Ivoni Susanti ${ }^{2}$, Dina Rahmawati ${ }^{3}$ \\ STKIP-PGRI Lubuklinggau ${ }^{1,2,3}$ \\ renydwiriastuti09@gmail.com ${ }^{1}$
}

\begin{abstract}
ABSTRAK
Tujuan penelitian ini untuk mengetahui jenis jamur makroskopis di Perkebunan Kelapa Sawit di Desa Rejosari Kecamatan Megang Sakti. Metode penelitian ini adalah kualitatif deskriptif. Tehnik pengambilan sampel menggunakan teknik purposive sampling dengan metode jelajah. Berdasarkan hasil penelitian yang dilakukan di Perkebunan Kelapa Sawit di Desa Rejosari Kecamatan Megang Sakti, jenis jamur yang diperoleh berjumlah 41 jenis. 38 jenis jamur termasuk dalam 8 ordo, 17 famili, 32 genus serta 3 jenis jamur makroskopis yang belum teridentifikasi. Pengamatan lingkungan abiotik jamur makroskopis di perkebunan kelapa sawit di Desa Rejosari antara lain, suhu udara berkisar antara $25-33^{\circ} \mathrm{C}$, kelembaban udara berkisar antara 50-97\%, kelembaban tanah berkisar antara 40$90 \%$, dan keasaman tanah $(\mathrm{pH})$ berkisar antara 6,5-7,5. Simpulan, dari ketiga lokasi ditemukan jamur yang dapat dikonsumsi, tidak dapat dikonsumsi dan berguna sebagai obat.
\end{abstract}

Kata Kunci : inventarisasi, jamur makroskopis, perkebunan kelapa sawit

\section{ABSTRACT}

The aim of the research was to find out the kinds of macroscopic fungi at oil palm plantations in Rejosari village Megang Sakti subdistrict. The method of the research was qualitative-descriptive. The sampling technique was purposive sampling with exploration method. The result showed that there were 41 kinds of fungi. 38 kinds included in 8 ordo, 17 famili, 32 genus and 3 unidentified macroscopic fungi. The observation results of abiotic environment of macroscopic fungi at oil palm plantations in Rejosari such as the air temperature was between 25-33 C, the air humidity was between 50-97\%, the soil humidity was between 40$90 \%$, and the scale of acidity $(\mathrm{pH})$ was between 6,5-7,5. In conclusion, at the three locations, it was found that there were the consumable fungi, nonconsumable fungi and medicinal fungi.

Keywords: stocktaking, macroscopic fungi, oil palm plantations

\section{PENDAHULUAN}

Indonesia merupakan negara yang memiliki hutan hujan tropis yang luas dengan keanekaragaman spesies yang tinggi, salah satu keanekaragaman tersebut yaitu jamur makroskopis (Alam, 2015). Darwis (2011) mengungkapkan bahwa Jamur makroskopis adalah jamur yang berukuran besar, sehingga dapat dilihat 
dengan kasat mata dan memiliki struktur umum yang terdiri atas bagian tubuh yaitu bilah, tudung, tangkai, cincin (volva).

Menurut Webster (2007), jamur makroskopis terdiri dari berbagai bentuk yaitu, jamur karang, jamur bola, jamur bintang, jamur tanduk dan jamur jelly. Mardji dan Noor (2009) memperkirakan jenis jamur makroskopis yang telah di ketahui di dunia sekitar 1.5 juta jenis jamur dan telah berhasil diidentifikasi, sedangkan di Indonesia terdapat 12.000 jenis yang sudah teridentifikasi dan terinventarisasi sampai saat ini.

Selain keanekaragamannya jamur juga perlu di ketahui manfaatnya, oleh karena itu perlu dilakukan eksplorasi dan inventarisasi jenis jamur makroskopis agar keanekaragaman dan manfaatnya dapat dimanfaatkan secara maksimal (Achmad, et al, 2013). Selanjutnya, Darwis (2011) mengungkapkan beberapa manfaat jamur ada yang dapat dikonsumsi karena mempunyai kandungan garam mineral yang tinggi serta memiliki vitamin $\mathrm{B}$ dan $\mathrm{D}$, sedangkan sebagai obat jamur dapat mencegah tumor dan kanker, namun ada juga jamur yang bersifat racun.

Secara alamiah jamur banyak dijumpai pada tempat dengan kondisi lingkungan yang lembab. Jamur memerlukan kondisi lingkungan yang kurang cahaya matahari karena jamur merupakan jenis tumbuhan yang tidak menyukai cahaya. Salah satu kawasan yang memiliki kondisi seperti ini adalah perkebunan kelapa sawit (Rahma, 2018). Salah satu lahan perkebuanan kepala sawit terbesar yang berada di Kecamatan Megang Sakti terletak di Desa Rejosari.

Perkebunan kelapa sawit di Desa Rejosari merupakan sumber utama penghasilan masyarakat. Perkebunan ini merupakan perkebunan yang luas yang di bangun pada tahun 1995 oleh PT Lonsum tbk (London Sumatra Indonesia) yang di kenal dengan perkebunan plasma.Geografis atau kondisi lingkungan diarea kebun kelapa sawit ini sangat cocok sebagai habitat jamur makroskopis sehingga banyak jamur makroskopis yang tumbuh. Namun disayngkan masyarakat Desa Rejosari banyak yang belum mengetahui manfaat dari setiap spesies jamur makroskopis yang ada.

\section{METODE PENELITIAN}

Jenis penelitian ini adalah Deskriptif Kualitatif dengan menggunakan metode observasi dan pengamatan langsung. Tehnik pengambilan sampel menggunakan purposive sampling dengan cara menyusuri setiap jalur pada lokasi pengamatan. Analisis data yang digunakan adalah pengukuran lingkungan abiotik jamur. Prosedur penelitian adalah jamur yang diperoleh di catat berdasarkan ciri morfologinya yaitu, warna jamur, bentuk jamur, tubuh buah jamur dan bentuk tangkai jamur. Kemudian jamur yang diperoleh di bawa ke laboratorium untuk di buat awetan basah.

Teknik pengumpulan data pada penelitian ini, yaitu dengan cara purposive sampling. Menurut Arikunto (2010), purposive sampling adalah teknik 
pengambilan sampel dengan tidak berdasarkan random, daerah atau strata melainkan berdasarkan atas adanya ciri-ciri khusus yang terfokus pada tujuan penelitian sehingga diharapkan dapat menjawab permasalahan dalam penelitian.Untuk memperoleh data yang dikehendaki, maka peneliti.melakukan prosedur pengumpulan data berupa observasi di lokasi pengamatan, wawancara dengan beberapa masyarakat Desa Rejosari untuk mendapatkan informasi mengenai manfaat dari jamur makroskopis yang diperoleh, catatan lapangan yang digunakan untuk mendesripsikan fenomena yang terjadi dan dokumentasi untuk memperkuat hasil dari penelitian.

\section{HASIL PENELITIAN}

Hasil pengamatan tentang jenis Jamur Makroskopis di Perkebunan Kelapa Sawit di Desa Rejosari Kecamatan Megang Sakti dapat di lihat pada tabel tabel. 1 berikut.

Tabel1 Inventarisasi Jenis Jamur Makroskopis di Perkebunan Kelapa Sawit

\begin{tabular}{|c|c|c|c|c|}
\hline Ordo & Famili & Genus & Spesies & Nama Daerah \\
\hline 1. Pezizales & 1. Sarcoscyphaloceat & 1. Cookeina & 1. C. Tricholoma & Jamur Terap \\
\hline \multirow{3}{*}{ 2. Aphylloporales } & \multirow{2}{*}{${ }_{s}$ 2. Lentinoceae } & \multirow[t]{2}{*}{ 2. Lentinus } & 2. L. Conatus & Tidak Diketahui \\
\hline & & & 3. L.Sajor-coju & Jamur Tui \\
\hline & 3. Schizophyllaceae & 3. Schizophyllum & 4. S. Commune & Jamur Grigit \\
\hline \multirow{13}{*}{ 3. Polyporales } & \multirow{6}{*}{ 4. Polyporaceae } & 4. Pycnoporus & 5. P. Cinnabarius & Jamur Merah \\
\hline & & 5. Daedaleopsis & 6. D. Confraggosa & Jamur Krikik 1 \\
\hline & & \multirow[t]{2}{*}{ 6. Coriolus } & 7. C. Pubescens & Jamur Krikik 3 \\
\hline & & & 8. C. Versicolor & Jamur Racun \\
\hline & & 7. Coltricia & 9. C. Perennis & Jamur Ati \\
\hline & & 8. Trementes & 10. T. Hirsuta & Tidak Diketahui \\
\hline & \multirow{3}{*}{ 5. Fomitopsidaceae } & 9. Daedalea & 11. D. Quercina & Tidak Diketahui \\
\hline & & & 12. D. Elegans & Jamur Racun \\
\hline & & 10. Phaeolus & 13. P. Schweinitzii & Jamur Iwak \\
\hline & \multirow{2}{*}{ 6. Meripilaceae } & 11. Rigidopus & 14. R. Microporus & Jamur Krikik 2 \\
\hline & & 12. Grifolla & 15. G. Frondosa & Jamur Dipa \\
\hline & 7. Meruliaceae & 13. Merulius & 16. M. Tremellosus & Tidak Diketahui \\
\hline & 8. Genodermataceae & 14. Genoderma & 17. G. Lucidum & Tidak Diketahui \\
\hline \multirow{3}{*}{ 4.Lycoperdales } & \multirow{3}{*}{ 9. Lycoperdoceae } & 15. Bovista & 18. B. Nigrescens & Tidak Diketahui \\
\hline & & 16. Calvatia & 19. C. Excipuliformis & Jamur Impes \\
\hline & & 17. Lycoperdon & 20. L. Pyriforme & Jamur Telor \\
\hline \multirow{8}{*}{ 5. Agaricales } & 10. Lepiotaceae & 18. Lepiota & 21. L. Cristata & Jamur Barat \\
\hline & \multirow{2}{*}{ 11. Plutaceae } & 19. Volvariela & 22. V. Volvaceae & Jamur Sawit \\
\hline & & 20. Pluteus & 23. P. Admirabilis & Tidak Diketahui \\
\hline & \multirow{5}{*}{12.} & \multirow[t]{2}{*}{ 21. Pleurotus } & 24.P. Ostreatus & Jamur Tiram \\
\hline & & & 25. P. Pulmonarius & JamurGromo \\
\hline & & 22. Armillariella & 26. A. Mellea & Jamur Payung 1 \\
\hline & & 23. Panus & 27. P. Rudis & Jamur Wulu \\
\hline & & 24. Mycena & 28. M. Haematopus & Jamur Kelapa \\
\hline
\end{tabular}




\begin{tabular}{|c|c|c|c|c|}
\hline \multirow{7}{*}{$T$} & \multirow[t]{5}{*}{ Tricholomataceae } & \multirow[t]{2}{*}{ 25. Marasmius } & 29. M. Oreades & Jamur Payung 2 \\
\hline & & & 30. M. Remealis & Tidak Diketahui \\
\hline & & \multirow[t]{3}{*}{ 26.Clitocybe } & 31. C.infundibuliformis & Jamur Payung \\
\hline & & & & Racun \\
\hline & & & 32. C. Desembris & Jamur Gagang \\
\hline & 13. Boletaceae & 27. Boletus & 33. B. Edulis & Tidak Diketahui \\
\hline & 14. Clavariaceae & 28. Ramariopsis & 34. Ramaria kunzei & Jamur Karang \\
\hline \multirow[b]{2}{*}{ 6. Xylariales } & \multirow[b]{2}{*}{ 15. Xylariaceae } & 29. Daldinia & 35. D. Concentric & Jamur Batu \\
\hline & & 30. Xylaria $s p$ & 36. Xylaria $s p$ & $\begin{array}{l}\text { Jamur Rambut } \\
\text { Sawit }\end{array}$ \\
\hline 7. Auriculariale: & 16. Auriculariaceae & 31. Auricularia & 37. A. Auricular & Jamur Kuping \\
\hline 8. Tremellales & 17. Tremelaceae & 32. Tremella & 38. T. Fuciformis & Tidak Diketahui \\
\hline
\end{tabular}

Sedangkan jenis jamur yang belum dapat diidentifikasi dapat dilihat pada tabel 2.

Tabel. 2 Inventarisasi Jenis Jamur Makroskopis Yang Belum Teridentifikasi

\begin{tabular}{cccll}
\hline No & Nama Daerah & Gambar & \multicolumn{2}{c}{ Deskripsi } \\
\hline 1 & Jamur Mata Kebau & & Struktur tubuh buah jamur \\
& & & \\
& &
\end{tabular}

2 Tidak Diketahui

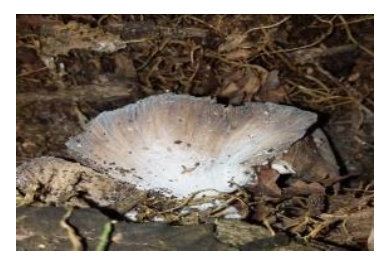

$3 \quad$ Tidak diketahui

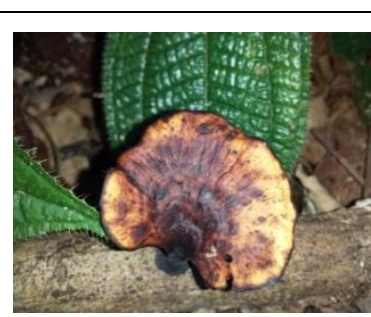

Bentuk jamur ini menyerupai kipas memiliki bilah di bagian bawah, ditemukan tumbuh pada kayu lapuk.

\section{Faktor Lingkungan Abiotik Perkebunan Kelapa Sawit}

Hasil pengukuran faktor lingkungan abiotik di perkebunan Kelapa Sawit di Desa Rejosari Kecamatan Megang Sakti, rincian pengukuran faktor lingkungan abiotik dapat dilihat pada Tabel 3 
Tabel.3. Faktor Lingkungan Abiotik Perkebunan Kelapa Sawit

\begin{tabular}{lcccc}
\hline Kelompok Tani & \multicolumn{4}{c}{ Lingkungan Abiotik } \\
\cline { 2 - 5 } & $\begin{array}{c}\text { Suhu Udara } \\
\left({ }^{0} \mathrm{C}\right)\end{array}$ & $\begin{array}{c}\text { Kelembaban Udara } \\
(\%)\end{array}$ & $\begin{array}{c}\text { Kelembaban Tanah } \\
(\%)\end{array}$ & pH Tanah \\
\hline Sido Mukti & $25-30^{\circ} \mathrm{C}$ & $50-75 \%$ & $40-90 \%$ & 6,5 \\
\hline Liam Indah 2 & $27-33^{0} \mathrm{C}$ & $51-84 \%$ & $60-65 \%$ & 7,5 \\
\hline Sido Makmur & $26-29^{\circ} \mathrm{C}$ & $83-97 \%$ & $40-80 \%$ & 6,5 \\
\hline
\end{tabular}

ManfaatJamur Makroskopis yang di temukan di Perkebunan Kelapa Sawit

Berdasarkan wawancara dengan beberapa warga Desa Rejosari dan analisis data dari beberapa literatur diperoleh beberapa jamur yang dapat dimanfaatkan sebagai bahan makanan maupun obat-obatan. Adapun uraiannya dapat di lihat pada tabel 4

Tabel. 4 Manfaat Jamur Makroskopis

\begin{tabular}{clll}
\hline \multirow{2}{*}{$\begin{array}{c}\text { Spesies Jamur } \\
\text { Makroskopis }\end{array}$} & \multicolumn{1}{c}{ Habitat } & \multicolumn{2}{c}{ Manfaat Jamur Makrokopis } \\
\cline { 2 - 4 } & & \multicolumn{1}{c}{ Masyarakat } & \multicolumn{1}{c}{ Literatur } \\
\hline 1. Cookeina tricholoma & Kayu-kayu & Dikonsumsi. Dapat & Dapat dijadikan obat \\
& lapuk, pelepah & dimasak untuk & untuk balita yang sering \\
& sawit & sayuran & kencing pada tengah \\
& & & malam (Sumarni, 2015)
\end{tabular}

\begin{tabular}{llcl}
\hline 2. Schizophyllum commune & $\begin{array}{l}\text { Kayu-kayu lapuk, Dikonsumsi. Dapat } \\
\text { pelepah sawit }\end{array}$ & $\begin{array}{l}\text { Dapat dijadikan sayuran } \\
\text { (Wahyudi, 2012) } \\
\text { atau makanan olahan }\end{array}$ \\
\hline 3. Pycnoporus cinnabarius & $\begin{array}{l}\text { Kayu-kayu } \\
\text { lapuk, pelepah } \\
\text { sawit }\end{array}$ & - & $\begin{array}{l}\text { Dapat dijadikan sebagai } \\
\text { olahan makanan (Webster) }\end{array}$ \\
\hline 4. Coriolus versicolor & Kayu lapuk & - & $\begin{array}{l}\text { Bila di fermentasikan dapat } \\
\text { menghasilkan zat antigen } \\
\text { yang berguna bagi }\end{array}$ \\
& & $\begin{array}{l}\text { yang pengindap kanker, selain itu } \\
\text { dapat mengobati infeksi } \\
\text { virus di hati termasuk } \\
\text { hepatitis B, dan hepatitis } \\
\text { kronis (Hasanuddin, 2014) }\end{array}$
\end{tabular}

\begin{tabular}{llll}
\hline 5. Phaeolus schweinitzii & Kayu lapuk & $\begin{array}{l}\text { Dikonsumsi. Enak } \\
\text { jika disayur. }\end{array}$ & \\
\hline 6. Grifolla Frondosa & Kayu lapuk & Dikonsumsi. & $\begin{array}{l}\text { Obat penurun berat badan, } \\
\text { pengatur tekanan darah, } \\
\text { glukosa, insulin, kolesterol } \\
\text { (Hasanuddin, 2014) }\end{array}$ \\
\hline
\end{tabular}




\begin{tabular}{llll}
\hline 7. Genoderma lucidum & Kayu lapuk & - & $\begin{array}{l}\text { Memiliki efek bersifat } \\
\text { melindungi organ tubuh, } \\
\text { mengobati, dan berdampak } \\
\text { positif terhadap } \\
\text { penyembuhan organ tubuh } \\
\text { yangsakit (Hasanuddin, } \\
\text { 2014) }\end{array}$ \\
\hline 8. Armillariella mellea & Kayu lapuk & & $\begin{array}{l}\text { Dapat dikonsumsi (Lincoff } \\
\text { dan Buezacky, 1982) }\end{array}$ \\
\hline 9. Mycena haematopus & Kayu lapuk & Dikonsumsi. Enak & $\begin{array}{l}\text { Tidak bisa dikonsumsi } \\
\text { (Lincoff dan Buezacky, } \\
\end{array}$ \\
& & jika disayur. & 1982)
\end{tabular}

\begin{tabular}{|c|c|c|c|}
\hline $\begin{array}{l}\text { 10. Calvatia } \\
\text { excipuliformis }\end{array}$ & Tanah & $\begin{array}{l}\text { Dikonsumsi. Dapat di } \\
\text { sayur jika masih muda } \\
\text { dan dapat dijadikan } \\
\text { sebagai obat luka. }\end{array}$ & $\begin{array}{l}\text { Dikonsumsi (Lincoff dan } \\
\text { Buezacky, 1982) }\end{array}$ \\
\hline 11. Lycoperdon pyriforme & Serasah & $\begin{array}{l}\text { Dikonsumsi. Enak } \\
\text { jika disayur. }\end{array}$ & $\begin{array}{lcc}\begin{array}{l}\text { Dapat dikonsumsi } \\
\text { buah }\end{array} \text { masih } & \text { mudika } \\
\text { (Wahyudi, 2016) } & \\
\end{array}$ \\
\hline $\begin{array}{l}\text { 12. Clitocybe } \\
\text { infundibuliformis }\end{array}$ & Tanah & - & $\begin{array}{l}\text { Dapat dikonsumsi (Lincof } \\
\text { dan Buezacky, 1982) }\end{array}$ \\
\hline 13. Volvariela volvaceae & $\begin{array}{l}\text { janjangan } \\
\text { kosong kelapa } \\
\text { sawit }\end{array}$ & $\begin{array}{l}\text { Dikonsumsi. Dapat } \\
\text { dijadikan sebagai } \\
\text { sayuran, namun bau } \\
\text { jamur ini tidak } \\
\text { enak. }\end{array}$ & $\begin{array}{lr}\text { Memiliki bahan aktif } \\
\text { antitumor, meningkatkan } \\
\text { daya tahan tubuh dan } \\
\text { berpengaruh } \\
\text { peningkatan terhadap } \\
\text { tubuh kesehatan } \\
\text { (Tjokrokusumo, 2015) }\end{array}$ \\
\hline 14. Pleurotus ostreatus & Kayu lapuk & $\begin{array}{lr}\text { Dikonsumsi. } & \text { Dapat } \\
\text { disayur } & \text { dan } \\
\text { dijadikan olahan } \\
\text { makanan. Namun } \\
\text { jika sudah tua } \\
\text { teksturnya akan } \\
\text { keras jika dimasak. }\end{array}$ & $\begin{array}{l}\text { Memiliki sumber bahan } \\
\text { biologi aktif yang dapat } \\
\text { dijadikan, sebagai bahan } \\
\text { baku untuk meningkatkan } \\
\text { daya tahan tubuh, yaitu } \\
\text { beta-glukan. } \\
\text { (Tjokrokusumo, 2015) }\end{array}$ \\
\hline 15. Pleurotus pulmonarius & Kayu lapuk & $\begin{array}{l}\text { Dikonsumsi, namun } \\
\text { kurangenak karena } \\
\text { teksturnya keras. }\end{array}$ & $\begin{array}{l}\text { Dikonsumsi. Selain itu } \\
\text { jamur ini juga berguna } \\
\text { dalam bidang obat-obatan } \\
\text { yaitu sebagai bahan dasar } \\
\text { serum glukosa, obat untuk } \\
\text { meningkatkan antibodi, } \\
\text { serta vitamin yang baik bagi } \\
\text { kuliti, (Hasanuddin, 2014) }\end{array}$ \\
\hline 16. Coltricia perennis & Kayu lapuk & Dikonsumsi. & - \\
\hline 17. Clitocybe desembris & Tanah & $\begin{array}{l}\text { Dikonsumsi. Enak } \\
\text { jika disayur }\end{array}$ & - \\
\hline 18. Boletus edulis & Tanah & - & $\begin{array}{l}\text { Dikonsumsi (Lincoff and } \\
\text { Buezacky, 1982) }\end{array}$ \\
\hline 19. Auricularia auricular & Kayu lapuk & $\begin{array}{l}\text { Dikonsumsi. Jika } \\
\text { disayur teksturnya } \\
\text { lembak. Namun, } \\
\text { jika dijadikan } \\
\text { tambahan pada } \\
\text { tekwan teksturnya } \\
\text { kenyal. }\end{array}$ & $\begin{array}{l}\text { Dikonsumsi karena } \\
\text { mengadung gizi dan } \\
\text { rasanya yang lezat, serta } \\
\text { dijadikan sebagai bahan } \\
\text { obat karena memiliki sifat } \\
\text { antiglukogan, antikoagulan } \\
\text { yang baik bagi kesehatan } \\
\text { (Hasanuddin, 2014) }\end{array}$ \\
\hline
\end{tabular}




\begin{tabular}{|c|c|c|c|}
\hline 20. Tremella fuciformis & Kayu lapuk & - & Sebagai bahan masakan dan \\
\hline & & & $\begin{array}{l}\text { untuk bahan dasar } \\
\text { minuman, juice dan es } \\
\text { cream serta digunakan } \\
\text { sebagai campuran bubur, } \\
\text { sup dan pencuci mulut } \\
\text { (Permana dan Purnawan, } \\
\text { 2015) }\end{array}$ \\
\hline 21. Jamur Mata kebau & Kayu lapuk & Obat luka & Tidak diketahui \\
\hline
\end{tabular}

Ket: - Tidak dimanfaatkan

Selain dapat dikonsumsi dan dijadikan obat, jamur juga dapat bersifat racun. Beberapa jamur yang diketahui bersifat racun jika dikonsumsi dapat di lihat pada tabel 5.

Tabel.5 Jenis Jamur Beracun

\begin{tabular}{|c|c|c|c|}
\hline \multirow{2}{*}{$\begin{array}{l}\text { Spesies Jamur } \\
\text { Makroskopis }\end{array}$} & \multirow{2}{*}{ Habitat } & \multicolumn{2}{|r|}{ Manfaat Jamur Makroskopis } \\
\hline & & Masyarakat & Literatur \\
\hline $\begin{array}{l}\text { 1. Maramius } \\
\text { remealis }\end{array}$ & $\begin{array}{l}\text { Kayu lapuk, } \\
\text { Janjangan } \\
\text { kelapa sawit, } \\
\text { pelapah sawit, } \\
\text { Serasah } \\
\end{array}$ & - & $\begin{array}{l}\text { Menghasilkan enzim yang dapat memecah } \\
\text { bahan organik yang kandungan seratnya } \\
\text { tinggi, sehingga dapat dijadikan sebagai } \\
\text { bahan tambahan untuk pembuatan pakan } \\
\text { ternak (Sulaksana dan Musandar, 2013) }\end{array}$ \\
\hline $\begin{array}{l}\text { 2. Marasmius } \\
\text { oreades }\end{array}$ & Tanah. & & \\
\hline $\begin{array}{l}\text { 3. Daldinia } \\
\text { concentrica }\end{array}$ & $\begin{array}{l}\text { Kayu-kayu } \\
\text { lapuk }\end{array}$ & $\begin{array}{l}\text { Sebagai obat } \\
\text { gatal }\end{array}$ & $\begin{array}{lr}\text { Mengasilkan } & \text { senyawa metabolit sekunder } \\
\text { berupa } & \text { dihydroisocoumarinyang }\end{array}$ \\
\hline 4. Xylaria $s p$ & Pelepah sawit & - & $\begin{array}{l}\text { bermanfaatsebagai antifungi dan mampu } \\
\text { menjadi inhibitor penyakit alzheimer. (Tanti, } \\
\text { 2018) }\end{array}$ \\
\hline
\end{tabular}

Ket: - Tidak dimanfaatkan

\section{PEMBAHASAN}

Berdasarkan hasil penelitian, jumlah jamur makroskopis yang ditemukan sebanyak 41 jenis jamur. Jamur makroskopis yang dapat diidentifikasi sebanyak 38 jenis, dari 8 ordo, 17 famili, dan 32 genus. 3 jenis jamur lainnya belum dapat diidentifikasikarena tidak di temukan urutan taksonominya, baik dari buku maupun sumber lain. Dari ke 41 jenis jamur yang diperoleh 35 jenis jamur termasuk dalam kelompok Basidiomycota, sedangkan 3 jenis jamur lainnya termasuk kedalam Divisi Ascomycota, yaitu Ordo Pezizales dengan spesies Cookeina tricholoma dan Ordo Xylarialles dengan spesies, Daldinia concentrica dan xylaria $s p$

Ordo Agaricales dan Ordo Polyporales merupakan jenis jamur makroskopis yang paling banyak ditemukan pada penelitian Hal itu dikarenakan jenis jamur ini memiliki tubuh buah besar dan mudah beradaptasi dengan kondisi lingkunga yang kurang mendukung bagi pertumbuhannya.Ordo ini memiliki 
kemampuan adaptasi yang baik terhadap lingkungan yang ekstrim serta didukung habitat yang sesuai bagijamur makroskopis yang termasuk ke dalam ordoini (Tampubolon 2012). Ordo Auriculariales merupakan ordo yang paling sedikit ditemukan pada saat penelitian yaitu hanya ditemuian 1 spesies saja. Sedangkan ordo Aphyoporales dan ordo Lycoperdales hanya ditemukan 3 spesies. Hal ini dikarenakan lingkungan yang kurang mendukung bagi pertumbuhan jamur tersebut sehingga mempengaruhi pertumbuhan dan penyebaran jamur jenis ini pada lokasi penelitian. Menurut Ulya (2017), faktor lingkungan sangat menentukan penyebaran dan pertumbuhan suatu organisme, yaitu setiap spesies hanya dapat hidup pada kondisi abiotik tertentu yang berada dalam kisaran toleransi yang cocok bagi organisme tersebut.

Lingkungan abiotik sangat mempengaruhi pertumbuhan jamur, jamur dapat tumbuh pada kisaran toleransi tertentu dan pada kondisi yang berbeda. Ahcmad, et al (2013) mengungkapkan bahwa faktor lingkungan sangat berperan dalam pertumbuhan jamur, diantaranya suhu, $\mathrm{pH}$, dan kelembapan. Perkebunan kelapa sawit di Desa Rejosari merupakan lokasi yang cocok bagi pertumbuhan jamur makroskopis hal ini disebabkan oleh faktor abiotik yang sangat medukung bagi pertumbuhan jamur tersebut yaitu suhu udaraberkisar antara $25-33^{\circ} \mathrm{C}$, kelembaban udara berkisar antara 50-97\%, kelembaban tanah berkisar antara 40$90 \%$ dan $\mathrm{pH}$ tanah berkisar antara 6,5-7,5. Hal ini sesuai dengan yang diungkapkan oleh Hasanuddin (2014) bahwakebanyakan jamur tumbuh antara $0^{\circ} \mathrm{C}$ sampai $35^{\circ} \mathrm{C}$, tetapi suhu terbaik untuk pertumbuhan jamur adalah $20-30^{\circ} \mathrm{C}$, kelembaban antara 80-97\% dan $\mathrm{pH}$ tanah antara 5-7,5.

Masyarakat Desa Rejosari mengungkapkan bahwa jamur biasa dikonsumsi karena memilki rasa yang enak dan gurih.Menurut Darwis (2011) Jamur dapat dikonsumsi karena mempunyai rasa yang enak serta mempunyai kandungan garam mineral yang tinggi dari pada yang dikandung dalam daging sapi atau daging domba. Jamur juga kaya akan vitamin B dan vitamin D yang berasal dari substitusi sinar matahari. Selanjutnya Tjokrokusumo (2015) mengungkapkan bahwa jamur dapat dijadikan sebagai obat karena memegang peranan penting dalam meningkatkan aktivitas anti tumor, $\beta$-glukan, juga menunjukkan sifathipokolesterolemik dan sifat antikoagulan.

Akhir-akhir ini jamur obat juga telah terbukti sebagai senyawa antisitotoksik,antimutagenik dan anti-tumorogenic, sehingga dapatdiharapkan sebagai promotor farmakologis kesehatan. Dari beberapa jenis jamur yang diketahui dapat dikonsumsi, disimpulkan bahwa yang paling sering dikonsumsi oleh masyarakat Desa Rejosari adalah Jamur grigit (Schizophyllum commune) dan jamur Tiram/Alot (Pleurotus ostreotus)karena jamur tersebut memiliki rasa yang enak, gurih dan kenyal, serta jamur tersebut juga dapat di jadikan sebagai makanan olahan seperti bakwan jamur dan crispy jamur, sehingga masyarakat Desa Rejosari banyak yang konsumsi jamur ini, untuk jenis jamur konsumsi lainnya mereka hanya mengkonsumsinya sesekali jika mereka menemukannya di dalam 
perkebunan. 2 jenis jamur lainnya belum dapat teridentifikasi manfaatnya dikarenakan masyarakat tidak pernah menemukan jamur ini, baik di perkebunan maupun di halaman rumah. Selain dapat dijadikan sebagai bahan makanan dan obat-obatan oleh masyarakat beberapa jamur tidak dimanfaatkan karena diketahui mengandung racun yang berbahaya bagi kesehatan. Jamur yang berwarna sangat mencolok, tidak terdapat gigitan dari organisme lain, memiliki bau busuk seperti bau telur busuk karena mengandung senyawa sulfida (H2S) ataupun bau ammoniak (NH3) atau senyawa sianida dapat di kategorikan sebagai jamur yang mengandung racun.

\section{SIMPULAN}

Jumlah Jamur makroskopis ditemui sebanyak 41spesies. 38 spesies termasukdalam 8ordo,17 famili, dan 32 genus.Sedangkan 3 spesies lainnya belumdapat diidentifikasi karena tidak diketahui urutan taksonominya, baik dari buku maupun sember lain. Hasil pengamatan lingkungan abiotik jamur makroskopis di perkebunan kelapa sawit di Desa Rejosari antara lain, suhu udara berkisar antara $25-33^{\circ} \mathrm{C}$, kelembaban udara berkisar antara 50-97\%, kelembaban tanah berkisar antara 40-90\%, dan keasaman tanah $(\mathrm{pH})$ berkisar antara 6,5-7,5. Jamur yang yang dapat dikonsumsidan bersifat pengobatanberjumlah 21 jenis, yang di ketahui bersifat racun namun dapat dimanfaatkan ditemukan 4 jenis, dan yang tidak dimanfaatkan karena diketahui mengandung racun yang berbahaya bagi kesehatan berjumlah 15 jenis jamur makroskopis.

\section{DAFTAR PUSTAKA}

Alam, N. (2015). Keragaman Jamur Basidiomycetes Makroskopis Di Kawasan Hutan Penddidikan Universitas Hasanuddin Bengo-Bengo Kecamatan Cenara Kabupaten Maros. Artikel.

Achmad. (2013). Panduan Lengkap Jamur. Jakarta: Penebar Swadaya

Arikunto, S. (2010). Prosedur Penelitian Suatu Pendekatan Praktik. Yogyakarta: Rineka Cipta.

Darwis, W. (2011). Inventarisasi Jamur yang Dapat Konsumsi Dan Beracun Yang Terdapat Di Hutan Dan Sekitar Desa Tanjung Kemuning Kaur Bengkulu. Jurnal Konservasi Hayati, 7 (2);1-8.

Hasanuddin. (2014). Jenis Jamur Kayu Makroskopis Sebagai Media Pembelajaran Biologi. Jurnal Biotik, 2 (1);1-76.

Mardji \& Noor. (2009). Keanekaragaman Jenis Jamur Makro Di Hutan Lindung Gunung Lumut. Jurnal Kehutanan Tropika Humida, 2 (2);143-155

Rahma, K. (2018). Karakteristik Jamur Makroskopis di Perkebunan Kelapa Sawit Kecamatan Meureubo Aceh Barat Sebagai Materi Pendukung Pembelajaran Kingdom Fungi di SMA Negeri 1 Meureubo. Universitas Islam Negeri Ar-Raniry, Aceh. 
Tampubolon, S. (2012). Keanekaragaman Jamur Makroskopis di Hutan Pendidikan Universitas Sumatera Utara Desa Tongkoh Kabupaten Karo Sumatera Utara. http://repository.usu.ac.id/bitstream/handle/123456789/52852/Cover.pdf?s equence $=7$

Tjokrokusumo, D. (2015). Diversitas jamur pangan berdasarkan kandungan betaglukan dan manfaatnya terhadap kesehatan. Jurnal: Pros Sem Nas Masy Biodiv Indon, 1(6) ; 1520-1521

Ulya, A. (2017). Biodiversitas Dan Potensi Jamur Basidomycota di Kawasan Kasepuhan Cisungsang, Kabupaten Lebak, Banten. Journal Of Biology, 10 (1); 9-16

Webster, J., \& Weber, W. S. (2007). Introduction to Fungi, Third Edition. Cambridge University: New York 